\title{
'This is My Fault, but Now I Know Online Game Addiction Is Not Good for Me': School Dropped Out Students' Narrative
}

\author{
$1^{\text {st }}$ S Aisyah \\ Department of English Education \\ Universitas Swadaya Gunung Jati \\ Jl Pemuda 32 Cirebon, Indonesia \\ $4^{\text {th }} \mathrm{F}$ Munifatullah \\ English Department \\ Universitas Lampung \\ Lampung, Indonesia
}

\author{
$2^{\text {nd }}$ Misdi \\ Department of English Education \\ Universitas Swadaya Gunung Jati \\ Jl Pemuda 32 Cirebon, Indonesia \\ misdirina@gmail.com
}

\author{
$3^{\text {rd }}$ Y Mumpuni \\ Department of English Education \\ Universitas Swadaya Gunung Jati \\ Jl Pemuda 32 Cirebon, Indonesia
}

\begin{abstract}
School dropped-out students have attracted educators and policy makers. A number of studies have investigated factors and number of the dropped out students. However, albeit of these studies, dropped out students' voice was reported. Thus, this paper is aimed at portraying dropped out student' voice. Their reason for dropping out and their wishes were sought. Of 114 respondents, three respondents were voluntarily recruited for an interview. The findings revealed they unintentionally opted for dropping out but situation led them to do so. Online game addiction was realized as a means for skipping their school matters. Not only this narrative provides different perspective on seeing the dropped out students but it also endows with new insights for policy makers in treating risky dropped out students. Educational implication and for further required research are also sought and discussed.
\end{abstract}

Keywords-Online Game, Addiction, School Dropped, Student

\section{INTRODUCTION}

Online game as one of the advanced technology products is often identified as one of factors for school students to opt school dropping out themselves. This possible as consuming online games lead to demotivate the student players in learning (1). Online game contributes to risky students go to further worse situation that leads to opt dropping out when cares are not paid well. Research reports $33 \%$ students decreasing their learning motivation and $67 \%$ were risky for losing their studying motivation (1). Online games offer attractiveness for their users and often for their players (2). This warns both school teachers and educators work harder pay attention in order to remind their students to use online games wisely.

Research reveals no positive correlation between playing video game and students' academic performance
(3). School engagement and environments, take for an example, peers in playing game, contribute positively for opting school dropping out (4). Albeit a number of studies have investigated negative impacts of online game for the school students due varies of reasons, e.g. $(1-3,5,6)$, in the context of Indonesian primary schools, online game and school dropped out students are rarely discussed widely. Thus, this paper is sought to investigate how do dropped out students reflect their online game addiction contribute to their new lives after dropping out?

\section{METHODS}

Employing a consecutive case study, this research situated in a coastal region in the West Java, Indonesia. Coastal regions are often recognized as sources distributing potential school dropped out. Primary school students prefer to work for helping their parents or even enjoyed their earned money for ineffective activities or fun. This praxis sends the regions as low income community with their negative social identities such as low literacy.

\section{A. Participants}

Of 48 participants, three school-dropped-out students voluntarily engaged in this study. They aged between 1618 year olds. These participants received and paid less academic attention from the parents and they work as pengamen (early aged music-based entertainers). They were recruited due to their willingness to participate in this study, their ability in providing details about their school dropping-out factors and their abilities for making reflection on this. Their reason as victim of online game addiction was mainly justified as the categorized as the most valid participants for this case study.

B. Data collection 
An interview was utilized to explore perspective of the dropped out students. The interview was conducted in relax and flexible approach where the three participants were encourage to discuss reasons and perspective of having dropped out schools. The interviews were conducted unintentionally as they relax. In relation to validity, key criteria of worthy topic, rich rigor, sincerity, credibility, resonance, significant contribution, ethics and meaningful coherence (7) were followed in this qualitative research. All recorded data were transcribed and confirmed to the participants.

\section{FINDINGS AND DISCUSSION}

This research aimed at portraying students' reflection due their dropped out school by online game addiction. The following is their narrative how online games brought their lives into negative experiences.

Actually, my school teachers were more attentive than my parents. They spent much time to educate us. However, being afraid of absent in completing the school tasks forced us not to attend their classes. I spent more time playing online game to forget them all (feeling secured). Too much enjoyed game had successfully forgotten all school matters (feeling secured) and sent me to opt stopping my study (dropping out decision). Join and had fun with my peers (negative peers and environment impact: satisfaction) after school time made me addicted for online game and finally I realized that I am now a dropped out student (regret)(Toni).

The school-dropped-out-students realize their existences are often judged negatively. Yet, they perceive this reality positively. They listen to what people say with their respects. The following excerpt proofs this...and it is hard to get the job (for dropped out students). With their graduate certificates, they find the job hard (struggling against graduate students: motivation). Now, we live unemployed and collect coins by giving street music services (feeling unemployed as amateur music players: self-reflection) and receive negative stigma from the society. This is my fault, but now I know online game addiction is not good for me (Ali).

Ali successfully evaluates his learning experiences, i.e. getting dropped-school, for his reflection for their future. He keeps motivated and fights against their peers who graduated for pursuing employment. As amateur music player, Ali stands by difficult situation around him. This shows how dropped-out students successfully do selfevaluation of what he did. This is rare. In other words, this kind of dropped-out students potential for being successful in the near future if they are directed to find his brighter future, instead of amateur music players.

Overall, the findings suggest people need to see dropped-out students critically. It needs to examine from different view instead of from negative sides. The findings imply not all dropped-out students will find their future as losers. In other word, paying reducing negative stigmas will lead them move easier. This is important as the closest society, e.g. family and community, contribute for their decision to drop out $(4,8)$

\section{CONCLUSION AND FURTHER RESEARCH RECOMMENDATION}

It concludes that, no-matter how significant it is, being dropped-out students potentially make positive contribution to the society throughout their activities. Constructive perspective and hands-in-hands are required to elevate dropped out students into their better future as empowered youths who experienced school dropped-outs. Due to limitation of the contexts, the results of the study suggest to discover further about impact of positive perception toward dropped-out students' learning and working motivation in the future research.

\section{ACKNOWLEDGMENT}

We would like to thank to Lembaga Penelitian Universitas Swadaya Gunung Jati for the research grant in 2018-2019

\section{REFERENCES}

[1] Chapman JR, Rich PJ. Does educational gamification improve students' motivation? If so, which game elements work best? J Educ Bus [Internet]. Routledge; 2018;93(7):314-21. Available from: https://doi.org/10.1080/08832323.2018.1490687

[2] Brunborg GS, Mentzoni RA, Melkevik OR, Torsheim T, Samdal O, Hetland J, et al. Gaming Addiction, Gaming Engagement, and Psychological Health Complaints Among Norwegian Adolescents. Media Psychol. 2013;16(1):115-28.

[3] Kert SB, Köşkeroğlu Büyükimdat M, Uzun A, Çayiroğlu B. Comparing active game-playing scores and academic performances of elementary school students. Educ 3-13. 2017;45(5):532-42.

[4] McDermott ER, Donlan AE, Zaff JF. Why do students drop out? Turning points and long-term experiences. J Educ Res [Internet]. Routledge; 2019;112(2):270-82. Available from: https://doi.org/10.1080/00220671.2018.1517296

[5] Cortázar A, Molina M de los Á, Sélman J, Manosalva A. Early Childhood Education Effects on School Outcomes: Academic Achievement, Grade Retention and School Drop Out. Early Educ Dev [Internet]. Routledge; 2020;31(3):376-94. Available

https://doi.org/10.1080/10409289.2019.1666445

[6] Cicchirillo V, Chory-assad RM, Cicchirillo V, Chory-assad RM. Effects of Affective Orientation and Video Game Play on Aggressive Thoughts and Behaviors Effects of Affective Orientation and Video Game Play on Aggressive Thoughts and Behaviors. J Broadcast Electron Media.

[7] 2016;8151(April):435-49.

[8] Tracy SJ. Qualitative quality: eight "big-tent" criteria for excellent qualitative research. Qual Inq. 2010; 16:837-51.

[9] Ivaniushina V, Alexandrov D. Anti-school attitudes, school culture and friendship networks. Br J Sociol Educ [Internet]. Routledge; 2018;39(5):698-716. Available from:http://doi.org/10.1080/01425692.2017.1402674 